\title{
Stories of hope and success in the food system
}

\author{
Food Tank is a non-profit organization that champions people in agriculture. Co-founder and President, Danielle \\ Nierenberg, discusses challenges faced by the farming community including youth engagement, equality for women \\ and preservation of indigenous practices. Farming should be better supported to ensure security of food supply.
}

What is the aim of Food Tank?

Food Tank was founded in 2013, and our overarching aim is to highlight stories of hope and success in the food system. We wanted to amplify the activities of individuals and organizations who work to alleviate hunger and obesity, prevent food loss and waste, improve opportunities for youth, provide more quality in the food system, promote regenerative practices - and more. Food Tank is a global platform for the food movement, and we want to reinforce respect for those who work in the food system. Farmers, food workers and others who labour to get food on our plates are not respected enough in society - they are certainly underpaid. Food Tank champions them; they are heroes - people who work extremely hard, under very difficult circumstances, in a crucial sector.

Are the challenges the farming community face comparable around the world?

Although they are often pitted against each other in terms of competition for global markets, there are actually a lot of similarities between the experiences of farmers in the global south and global north. Farmers all over the world have suffered a lot because of policies that don't support them.

The farming community is ageing everywhere. In the US and in African countries, the average age of farmers is around 60 years old. Young farmers struggle to get a foothold in the industry. They want to be part of the food system, but may be burdened by student loan debt or lack of healthcare. Many are not from farming backgrounds and don't have access to land or the mentors who can teach them the business of farming.

We must respect farmers as business men and business women. They must be given the tools to understand markets and distribution systems. Unfortunately, across the world there has been a dramatic decline of extension services. Farmers need extension agents who provide information - not sales representatives - to call upon to help them do their job.

There is another set of challenges faced specifically by women who farm.

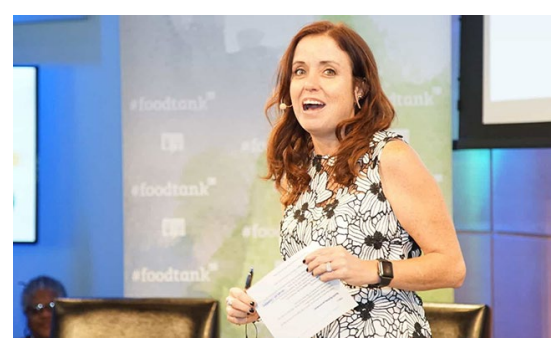

Credit: Food Tank

Women make up about $43 \%$ of the global agricultural labour force; in many parts of sub-Saharan Africa up to $80 \%$ of farmers are women. Women farmers do not get the same resources as men - they don't get access to land, education, banking and financial services. Women produce at least half of the food in the world, and face immense discrimination as they do so.

Put simply, farmers across the world face similar foundational challenges, and they must be given the support they need to do their job. There is an urgency to enabling the work of farmers as the world grapples with issues of food security in climate change and food system resilience to shocks such as COVID-19. Aside from policy to mitigate the challenges farmers face, society must foster respect for the people who grow, harvest, process, distribute and serve our food. These are jobs that are often considered low-skilled and dispensable, but we have come to realize during the COVID-19 pandemic that they are 'frontline'. That change of mindset is really important.

Can you give an example of the kind of positive initiatives in agriculture that inspire your work?

Positive stories need to be highlighted. Several years ago, I met a group of about 50 women farmers in Niger who had formed a co-operative - they had received funding from the International Crops Research Institute for the Semi-Arid Tropics (ICRISAT). The women used solar drip irrigation systems to grow crops for home and local markets. They managed a farm together and developed business skills. Before they banded, these women made roughly US\$300 per year; when I spoke to them, they were making US $\$ 1,500$ per year.

The true value of the co-operative was, however, much more transformative. The women reported buying bicycles for their husbands so that they could go to work, sending their children to school, purchasing books, affording healthcare and supporting better nutrition and health for their families.

Furthermore, the empowerment of women such as these has multigenerational impacts that go well beyond the here and now. For children, both girls and boys, seeing their mother empowered - a business woman and more - is deeply enriching and consolidates respect for women and girls. These kinds of examples are small, and not as widespread as they could or should be, but in my view they are the things that are really transformational.

Is there a line to be drawn from these small-scale and local examples to global thinking around food security?

Yes; I maintain that a fundamental transformation, at local and global levels, has to be the view of farming as a desirable profession - not a life one is forced into because of limited education, wealth or ability to migrate. There are a lot of non-profit organizations reigniting an interest in local, traditional and indigenous foods - for good reason. Indigenous crops, many phased out due to export crops, should be considered foods of the future. They are often resilient to pathogens, disease, flooding or drought. As climate change becomes more of an issue, we should concentrate on these crops for nutrition and food security. Indigenous foodways are also incredibly important for preserving traditional, cultural and societal values.

I am Food Champion of The Crop Trust, which is based in Norway. This organization preserves indigenous crops in seed banks. It also tries to re-establish the traditions around indigenous crops encouraging people to eat them and companies to invest in them as ingredients. There needs to be greater commitment to producing indigenous crops and to ensuring farmers are paid in a fair way, including for the ecosystem services they provide by growing them. The world needs that genetic 
diversity to maintain food supplies for future generations.

What political actions are needed to mitigate the challenges, and avail of the opportunities, that you have described for farming and food?

There are non-profits supporting a lot of the positive work I describe, but what you really need is governments investing in young farmers, and they're not doing that. It is a fundamental point - who is going to grow food of the future if youth are not supported in farming? This is a crucial area where policy needs to be implemented, and implemented soon for food security.

It serves the interests of international governments, European, American and more, to support agriculture in resource-poor regions of the world. Food security contributes in no small way to national and international security. In societies where people are hungry and don't have opportunities for employment, the potential for crime, subversive or terrorist activities increases. Research shows that when people are deprived of education, are hungry and don't have jobs, terrorist groups offer food and money - exploiting vulnerabilities that could be mitigated by supported food and agriculture. Aid and the support of food and agricultural development is good for all of us.

How does Food Tank operate in the spheres you have described?

Food Tank began with the aim of switching how food system stories are told. I found that environmental organizations, in the mid-2000s at any rate, were focused on highlighting problems rather than solutions. I had travelled all over the world and saw innovative projects that, if they had a little more research or investment, could be scaled up and replicated in different ways. At Food Tank, we believe we are filling a gap in how people view food issues - we try to highlight what is working, to shine a spotlight on it.

We try to have a diverse funding stream with investment from foundations and partnerships as well as members (who give anywhere from US $\$ 5$ to US\$2,000 annually) to support our efforts. We try to operate in a non-biased way politicians from all sides speak at our summits; I will speak at social justice and for example corporate conferences. Our newsletter reaches more than 300,000 people across the world; we put out reports like The True Cost of and The Importance of Farming Across the Globe. Our first book Nourished Planet: Sustainability in the Global Food System was published in 2018; we're now working on a book on food loss and food waste. Another major aspect of our work is convening events. We bring together a diversity of groups from the food system - be it indigenous people, climate-concerned consumers or corporations. We want people to speak bluntly, have open conversations, and that is critical to how we do our work.

Interviewed by Anne Mullen

Published online: 19 May 2020

https://doi.org/10.1038/s43016-020-0084-Z 